\title{
Obstetric factors and pregnancy outcome in placenta previa
}

Ojha N.

Department of Obstetrics and Gynecology, Tribhuvan University Teaching Hospital, Kathmandu

Correspondence address: Dr Neebha Ojha, TU Teaching Hospital, Kathmandu, Nepal

E-mail: neebha.ojha@gmail.com

\begin{abstract}
Introduction: Placenta previa is one of the major causes for maternal morbidity and mortality. The aim of this study was to analyze the obstetrical factors associated with placenta previa and to find out the maternal and perinatal outcome of these cases.

Methods: This was a retrospective study conducted in the Department of Obstetrics and Gynecology of TUTH. Hospital chart records of four years (1st January 2008 to 31st December 2011) were collected. Chart records of all women who had undergone cesarean section for placenta previa were reviewed. Relevant clinical findings were noted.

Results: During the study period, there were 82 cases of cesarean sections done for placenta previa, which is $0.55 \%$ of the total deliveries.

Of the eighty two cases, charts could be obtained of the 70 patients for the analysis. $21.4 \%$ had total placenta previa. Maximum women were in age group 26-30 years. Sixty one percent of the patients were multipara. Sixteen patients had history of cesarean section and 20 cases had abortions in previous pregnancy. Malpresentation was present in more than one fifth $(21.4 \%)$ of the patient.

$45.7 \%$ of the babies were preterm and $27 \%$ were low birth weight babies. Seven babies had neonatal death.

Almost one third (31.4\%) of the patient had blood loss $\geq 500 \mathrm{ml}$. There were four cases with blood loss $\geq 1000 \mathrm{ml}$. Among them two had loss of more than two liters. Ten patients required blood transfusion. One patient had cesarean hysterectomy.

Conclusion: Placenta previa poses danger to both the mother and the baby. There is high maternal morbidity and adverse perinatal outcome.
\end{abstract}

Key words: maternal and perinatal outcome, placenta previa, risk factors

\section{Introduction}

Placenta previa is used to describe a placenta that is implanted over or very near the internal os. 1 It is one of the major cause for antepartum hemorrhage, which complicates two to five percent of the pregnancies. 2 The incidence of placenta previa is approximately 4-5 per 1000 deliveries.3, 4 Placenta previa is graded into different types depending on how close is the lower margin of the placenta to the internal os and whether it is situated anterior or posterior wall of the uterus. 5
There are several factors, especially obstetrical, which has been found to be associated with placenta previa. Advancing maternal age, multiparity, previous cesarean delivery, previous abortions etc has been associated with increased risk of placenta previa. The adverse maternal outcome like postpartum hemorrhage, cesarean hysterectomy, increased need for blood transfusion are dreaded complications.2,6 Higher risk of preterm birth, low apgar score, congenital malformation increases the perinatal morbidity and mortality. 2,7 
The objective of the study was to analyze the obstetrical factors associated with placenta previa and to find out the maternal and perinatal outcome of these cases.

\section{Methods}

This was a retrospective descriptive study conducted in the Department of Obstetrics and Gynecology of TUTH. Hospital chart records of four years (1st January 2008 to 31st December 2011) were collected. Chart records of all women who had undergone cesarean section for placenta previa were reviewed. Detail information regarding patient's management and other relevant clinical findings were noted.

\section{Results}

During the study period, there were a total of 4847 cesarean sections among 14,948 deliveries which accounts for $34.4 \%$ cesarean section rate. Among these, there were 82 cases of cesarean sections done for placenta previa, which is for $0.55 \%$ of the total deliveries.

Of the eighty two cases, charts could be obtained of the 70 patients for the analysis of this study. Of the total LSCS $40(57 \%)$ cases were emergency operations. Twenty nine (41\%) cases presented with bleeding per vagina.

Table 1 shows the type of placenta previa. Major placenta previa (total and partial) constituted $35.7 \%$ of the all placenta previa cases. Of these $21.4 \%$ had total placenta previa. Maximum women presented with marginal placenta previa $(38.6 \%)$.

Table 1: Type of placenta previa

$\begin{array}{ll}\text { Type of placenta previa } & \text { N (\%) } \\ \text { Low lying } & 18(25.7) \\ \text { Marginal } & 27(38.6) \\ \text { Partial } & 10(14.3) \\ \text { Total } & 15(21.4) \\ \text { Total } & 70(100.0)\end{array}$

Maximum women were in age group 26-30 years. Five patients were above 35 years old. (Figure 1)

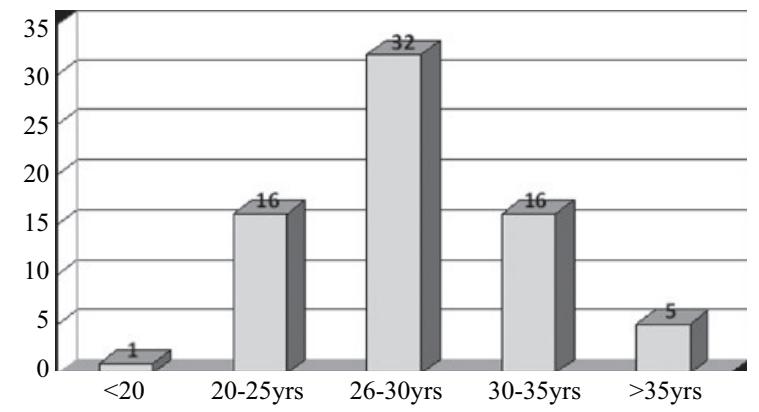

Fig. 1: Age distribution of the patient

Table 2 shows the obstetric factors related to placenta previa: Forty three $(61 \%)$ of the women were multipara. Sixteen patients had history of cesarean section (two cases had previous two cesarean section) and 20 cases had abortions in previous pregnancy. Of these 8 had both cesarean section and abortion.

Table 2: Obstetric profile of the women

\begin{tabular}{|c|c|}
\hline Obstetric profile & $\mathrm{N}(\%)$ \\
\hline \multirow[t]{2}{*}{ primipara } & $27(38.6)$ \\
\hline & $43(61.4)$ \\
\hline Previous LSCS & $16(22.8)$ \\
\hline Previous abortion & $20(28.6)$ \\
\hline Previous LSCS and abortion & $8(11.4)$ \\
\hline Previous MRP & $1(1.4)$ \\
\hline Uterine anomaly & $1(1.4)$ \\
\hline Malpresentation & $15(21.4)$ \\
\hline \multicolumn{2}{|l|}{ Placental factors } \\
\hline \multicolumn{2}{|l|}{ (placenta succenturata, } \\
\hline morbid adhesion, vasa previa each) & $3(4.3)$ \\
\hline
\end{tabular}

Regarding abortion, $37 \%$ of cases had induced abortion and $50 \%$ of cases had more than one abortion. One patient had up to four abortions.

Malpresentation was present in more than one fifth $(21.4 \%)$ of the patient. There were three cases with placental abnormality as seen in table 2 .

Table 3 shows neonatal outcome. $45.7 \%$ of the babies were preterm and $27 \%$ were low birth weight babies. Seven $(10 \%)$ of the babies had apgar score $<5$ at 5 minutes. There were seven neonatal deaths. One baby was anomalous with club foot and ambiguous genitalia. 
Table 3: Neonatal outcome

$\begin{array}{lll}\text { Factors } & & \text { N }(\%) \\ \text { Maturity (Weeks) } & <28 & 3(4.3) \\ & 28-33 & 13(18.6) \\ & 34-36 & 16(22.8) \\ & >37 & 38(54.3) \\ \text { Birth weight }(\mathrm{kg}) & <1.5 & 9(12.8) \\ & 1.5-2.4 & 10(14.3) \\ & 2.5-3.5 & 49(62.0) \\ \text { Preterm birth } & >3.5 & 2(2.8) \\ \text { Low birth weight babies } & 32(45.7) \\ \text { Apgar score (<7 in 5 minutes) } & 19(27.1) \\ \text { Early neonatal death } & 7(10) \\ \text { Still birth } & 7(10) \\ \text { Male babies } & 1(1.4) \\ \text { Congenital anomaly } & 40(57.1) \\ \end{array}$

Looking at the obstetric complications shown in Table 4, almost one third (31.4\%) of the patient had blood loss $\geq 500 \mathrm{ml}$. There were four cases with blood loss $\geq 1000 \mathrm{ml}$. Among them two had loss of more than two liters. Ten patients required blood transfusion. One patient required cesarean hysterectomy.

Table 4: Obstetrical complications

$\begin{array}{lll}\text { Factors } & \mathrm{N}(\%) \\ \text { Postpartum hemorrhage } & \geq 500 \mathrm{ml} & 22(31.4) \\ & \geq 1000 \mathrm{ml} & 4(5.7) \\ \text { Blood transfusion } & 10(14.3) \\ \text { Associated abruptio placenta } & 3(4.3) \\ \text { Cesarean hysterectomy } & 1(1.4) \\ \text { (ass morbid placental adhesion } & \\ \text { and bladder injury) } & \end{array}$

\section{Discussion}

Placenta previa is one of the dreaded complications in obstetrics due to its associated adverse maternal and perinatal outcome. In this study, the incidence of placenta previa undergoing cesarean section was found to be $0.55 \%$ of total deliveries. Various studies have shown the incidence of placenta previa ranging from 0.33 to $0.38 \%$ of deliveries.2,6 In the meta analysis reviewing studies on placenta previa between 1950-1996, among 13,992 patients diagnosed with placenta previa the reported incidence of placenta previa ranged from $0.28-2.0 \%$ or approximately 1:200 deliveries.4 This incidence is similar to this study.

Increasing age and number of pregnancies have been shown to be an important risk factor for placenta previa. This study had one third of the patient above 30 years age group and almost two third $(61 \%)$ of the women were multipara. According to Cleary et al, a prospective database from multicenter investigations of 36,056 women with singletons showed increasing age was significantly associated with placenta previa comparing women less than 35 years to $35-29$ years and 40 years and older (OR 1.8 and 2.8 respectively). 8 Multiple studies have shown increasing parity to be an important risk factor for placenta previa.9, 10,11

Regarding previous obstetric history, $22.8 \%$ had previous LSCS while more than one fourth $(28.6 \%)$ had history of abortion. In a retrospective cohort study of 399,674 women, the rate for placenta previa at second birth for women with first vaginal birth was 4.4 per 1000 births, compared to 8.7 per 1000 birth for women with cesarean section at first birth. After adjustment cesarean section at first birth remained associated with increased risk of placenta previa (OR 1.6 95\% CI 1.44-1.76).12 Previous history of abortions (both spontaneous and induced) have been significantly associated with up to three times risk of placenta previa. $2,4,13,14$

In population based retrospective cohort study in Nova Scotia, Canada from 1988-1995, 308 cases of placenta previa were identified. Maternal complications included postpartum bleeding (RR-1.86), hysterectomy (RR-33.26), blood transfusion (RR-10.05), septicemia (RR-5.55). Risk factor for hysterectomy in women with placenta previa included presence of placenta accrete and previous cs.6 This is similar to the case of cesarean hysterectomy this study who had history of previous cesarean section and there was morbid placental adhesion. Sheiner et al found pregnancies complicated by placenta previa had significantly higher rate of postpartum hemorrhage (OR3.8, 95\%CI 1.2-10.5), malpresentations (OR7.6, 95\%CI5.7-10.1), abruption placenta (OR 13.1, 95\% CI 8.2-20.7).2

A population based retrospective cohort study among singleton 544,734 mother-infant pair showed that the association between low birth weight and placenta previa is chiefly due to preterm delivery and to lesser extend to fetal growth restriction.7 Sheiner showed that congenital malformations and perinatal mortality was 2.6 times more common among cases with placenta previa as compare to 
those without it. 2 In this study $27 \%$ of babies had low birth weight and $10 \%$ of the babies had neonatal death. Increased perinatal mortality as well as neonatal death has been noted in other studies. 15,16

\section{Conclusion}

There were 82 cases of cesarean sections done for placenta previa, which is for $0.55 \%$ of the total deliveries. $21.4 \%$ had total placenta previa. There were four cases with blood loss $\geq 1000 \mathrm{ml}$. Among them two had loss of more than two liters. Ten patients required blood transfusion. One patient required cesarean hysterectomy. $45.7 \%$ of the babies were preterm and $27 \%$ were low birth weight babies. Seven babies had neonatal death and there was one anomalous baby.

\section{References}

1. Gupta B, Misra R. Antepartum Haemorrhage. In: Misra R (Ed) Ian Donald's Practical Obstetric Problems. 6th edn. New Delhi. BI Publications Pvt Ltd, 2007;310-332.

2. Sheiner E, Shoham-Vardi I, Hallak M, Hershkowitz R, Katz M, Mazor M.Placenta Previa: obstetric risk factors and pregnancy outcome. The Journal of Maternal-Fetal and Neonatal Medicine 2001;10(6):414-19.

3. Faiz AS, Ananth CV. Etiology and risk factors for placenta previa: an overview and meta-analysis of observational studies. Journal of Maternal-Fetal and Neonatal Medicine 2003;13(3):175-90.

4. Ananth CV, Smulian JC, Vintzileos AM. The association of placneta previa with history of cesarean delivery and abortion: A metaanalysis. AJOG 1997;177(5):1071-78.

5. Cunningham FG, Leveno KJ, Bloom SL, Hauth JC, Rouse DJ, Spong CY. Obstetrical Hemorrhage. 23rd edn. New York. McGraw-Hill Companies,2010 ;757803

6. Crane JM, Van den Hof MC, Dodds L, Armson BA, Liston R. Maternal complications with placenta previa. Am J Perinatol 2000;17(2):101-5.

7. Ananth CV,Demissie K, Smulian JC, Vintzileos AM. Relationship among placenta previa, fetal growth restriction and preterm delivery: a populationbased study. Obstet Gynecol 2001;98(2):299-306.

8. Cleary-Goldman J, Malone FD, Vidaver J, Ball RH, Nyberg DA, Comstock CH, et al. Impact of Maternal Age on Obstetric Outcome. Obstet Gynecol 2005;
105:983-90.

9. Babinszki A, Kerenyi T, Torok O, et al. Perinatal outcome in grand and great-grand multiparity: Effects of parity on obstetric risk factors. Am J Obstet Gynecol 1999;181:669.

10. Parazzini F, Dindelli M, Luchini L, La Rosam M, Petenza MT, Frigerio L, Ferrari A. Risk factors for placenta previa. Placenta 1994;15(3):321-6.

11. Gilliam M, Rosenberg D, Davis F. The likelihood of placenta previa with greater number of cesarean delivery and higher parity. Obstet Gynecol2002;99(6) :976-80.

12. Gurol-Urganchi I, Cromwell AC. Edozien, LC, Smith GCS, Onwere C, Mahmood TA, et al. Risk of placenta previa in second birth after first birth cesarean section: a population-based study and meta-analysis. BMC Pregnancy and Childbirth 2011;11:95.

13. Johnson LG, Mueller BA, Daling JR. The relationship of placenta previa and history of induced abortion. Int J Gynecol Obstet 2003;81(2) :191-8.

14. Hung TH, Hsieh CC, Hsu JJ, Chiu TH, Lo LM, Hsieh TT. Risk factors for placenta previa in an Asian population. Int J Gynecol Obstet 2007;97(1):26-30.

15. Crane JM, Van den Hof MC, Dodds L, Armson BA, Liston R. Neonatal outcome with placenta previa. Obstet Gynecol 1999;93:541-4.

16. Ananth CV, Smulian JC, Vintzileos AM. The effect of placenta previa on neonatal mortality: a population based study in United States 1989 through 1997. Am J Obstet Gynecol 2003;188:1299-304. 